\title{
The Power of Continuing Professional Development on EFL Teachers' Creativity
}

\author{
*Fatemeh Mohammadifar: English Department, Tabaran Institute of Higher Education, Mashhad, Iran \\ Mona Tabatabaee-Yazdi: English Department, Tabaran Institute of Higher Education, Mashhad, Iran.
}

\begin{abstract}
Creativity has played a leading role in education that not only attracts many learners but also teachers. According to Ismail, Desa, and Balakrishnan (2018) creativity is one of the main skills that is extremely noticeable in teaching. Moreover, because of the alteration of generation and expansion of knowledge and technology, the instruction requires creative teachers that can use up-to-date and modern techniques. Within this framework, the researcher tried to investigate any significant relationship between Iranian EFL teachers' Continuing Professional Development (CPD) and their creativity. To comply with the objective, a total of 210 Iranian EFL teachers took part in this study. For gathering the data two questionnaires were administered through Google Form that shared via social media like Telegram and WhatsApp. The results of correlation analyses revealed that there was a positive significant relationship between Iranian EFL teachers' CPD and their creativity. Accordingly, this study proposed a structural model to examine CPD factors contributing to EFL teachers' creativity. Due to the outcome of SEM, collaborating is the best predictor of Iranian EFL teachers' creativity. Moreover, this study provides evidence that there is no significant difference in the level of Iranian EFL teachers' creativity between male and female teachers and years of teaching experience. Together these results provide important insights into the significant role of CPD on the teachers' creativity. These findings provide a potential mechanism for teachers, supervisors, and administrators of English language institutes or schools to elevate teachers' creativity knowledge, and education by applying beneficial practices and activities of CPD.
\end{abstract}

Key words: Continuing professional development, Creativity, EFL Teachers, SEM.

JEL Classification: I23 Higher Education; Research Institutions.

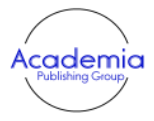

International Journal of Educational Studies

Volume 4, Issue 1, pp. 1-9 2021

DOI: $10.53935 / 2641-533 x . v 4 i 1.50$

Corresponding Author: Fatemeh

Mohammadifar

Email: mohammadifarf1994@ omailcom

Funding: This study received no specific

financial support.

Article History:

Received: 28 June 202

Revised: 30 July 2021

Accepted: 19 August 202

Published: 1 September 2021

(C) 2021 by the authors; licensee Academic Publishing Group

\section{Introduction}

One of the most important factors in educational settings, that essentially influences the learning outcomes of the learners, is the teachers' roles (Komba \& Nkumbi, 2008). Accordingly, Continuing Professional Development (CPD) is one factor for teachers to grow their qualities as the key role model in education. CPD is defined as longstanding professional development practice which is crucial to obtain competence and qualified teachers in a dynamic organization (Ukpo, 2005). CPD, as a key factor in education, assists the teachers in changing learning from passive to proactive. Thus, by providing professional techniques and strategies, CPD helps teachers with different proficiency to prepare for the uppermost performance and be able to enhance and facilitate learning and teaching practices. Besides, research showed that for teaching and learning a new language some factors such as motivation, self-esteem, self-efficacy, anxiety, and creativity are important (Seddigh \& Shokrpour, 2013).

In this regard, Sternberg (1985) expounded creativity as imagination, unconventionality, risk-taking, flexibility, and creating new classification and systematization of knowledge. Therefore, creativity makes teachers flexible and independent and helps them to be more effective in the learning of their students (Dewi, 
2019). In most educational institutes, creativity is the crucial criterion for selecting teachers since creative techniques attract learners to gain knowledge of a subject effortlessly and learners are eager to take part in educational courses constantly. Besides, creativity gives rise to highly competitive performance in educational settings (Appu, Sia, \& Sahoo, 2015). Thus, lack of creativity in teachers, which often have been observed by monotonous methods of teaching, leads to a lack of learners' excitement and learning motivation. Therefore, teachers' creativity needs to be a key factor in any educational environment so that learners master the subject with a creative mind and powerful activities in the classroom. Moreover, because of the alteration of generation and expansion of knowledge and technology, the instruction requires creative teachers that can use up-to-date and modern techniques. Therefore, creativity makes teachers flexible and independent and helps them to be more effective in the learning of their students. Moreover, the interaction of teachers with students not only can reinforce teachers' creativity but also follow the enhancement of students' creativity (Soh, 2000). Besides, the action of teachers can also affect students' creative effort, results, and personal characteristics (Rhodes, 1987). Consequently, creative teachers can aid in the improvement of teaching strategies in order to give learners the courage to spread study skills and real potential. Therefore, the researchers in this study aimed to find out if CPD programs and strategies can be considered as the predictive power of their creativity. To address this aim, a structural model was hypothesized between the CPD constructs and overall creativity Figure 1, and the following research questions were posed:

Q1: Is there any significant relationship between Iranian EFL teachers' Continuing Professional Development (CPD) and their creativity?

Q2: Which construct of Continuing Professional Development (CPD) is the best predictor of Iranian EFL teachers' creativity?

Q3: Does gender have any significant effect on Iranian EFL teachers' creativity?

Q4: Does years of teaching experience have any significant effect on Iranian EFL teachers' creativity?

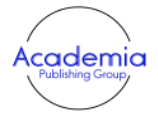

International Journal of Educational Studies

Volume 4, Issue 1, pp. 1-9

2021

DOI: $10.53935 / 2641-533 x . v 4 i 1.50$

Corresponding Author: Fatemeh

Mohammadifar

Email: mohammadifar.f1994@gmail.com

Funding: This study received no specific

financial support.

Article History:

Received: 28 June 202

Revised: 30 July 2021

Accepted: 19 August 2021

(C) 2021 by the authors; licensee Academic Publishing Group

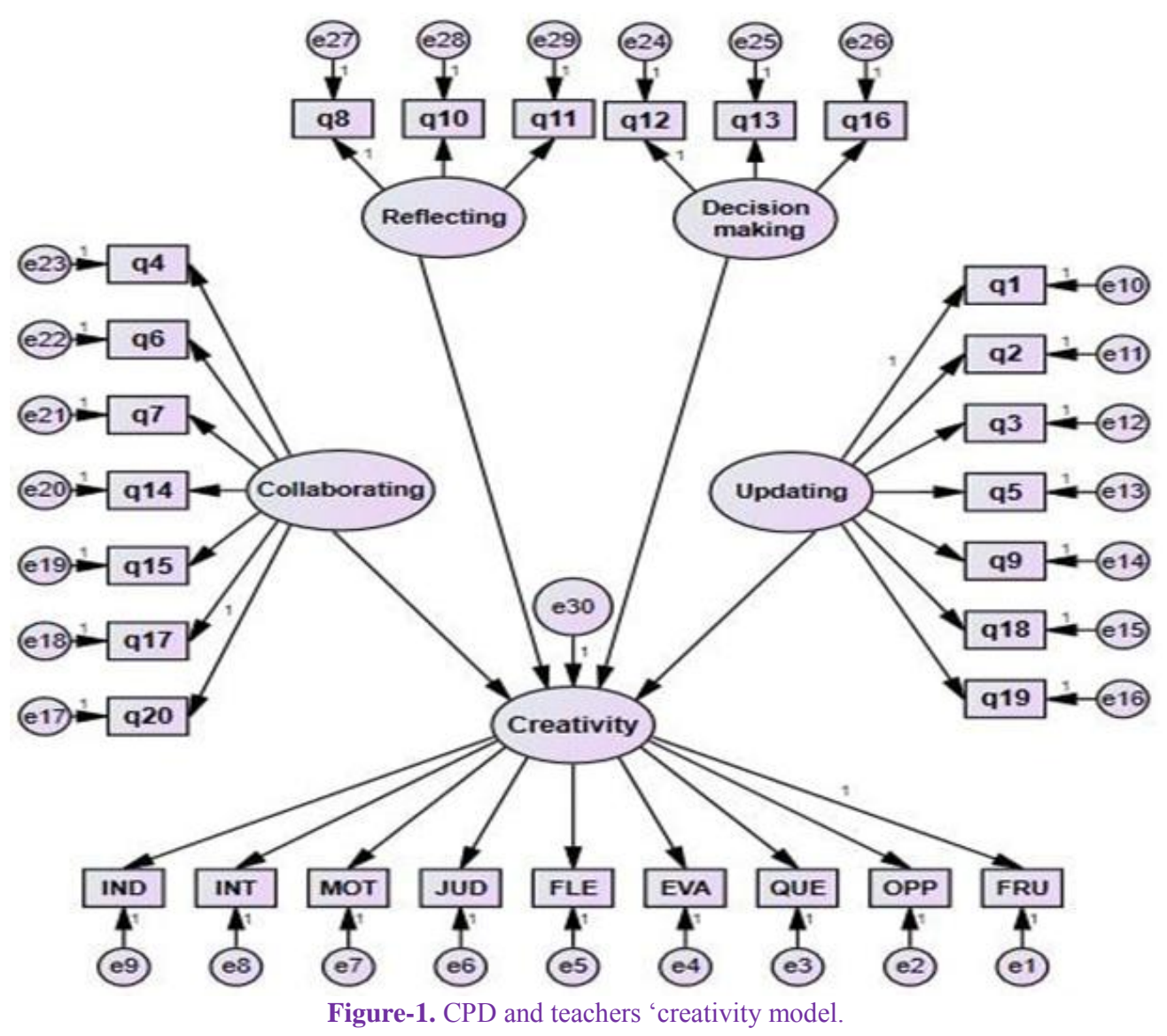




\section{Review of Literature}

According to Fadl (2019) various terms are used concerning CPD in education settings. Professional development, professional learning, professional growth, in-service education, in-service learning, renewal, continuing professional development, in-service trading, on-going assistance, human resource development, recurrent education, continues career development, lifelong learning, and professional growth are just a few of such terms. In this article, CPD stands for 'Continuous' or 'Continuing Professional Development' and broadly signifies the process of the continuing growth of a professional after joining the profession (Padwad \& Dixit, 2011). CPD is a planned, continuous, and lifelong process whereby teachers try to develop their personal and professional qualities and improve their knowledge, skills, and practice which lead to their empowerment, the improvement of their agency, and the development of their organizations and their pupils (Padwad \& Dixit, 2011). The Institute of Personnel and Development of the United Kingdom defines CPD as a constant keeping up-to-date (updating) of the professional knowledge throughout the entire working life through systematic, informal, or self-directed learning models (Refrigeri, 2018). However, unfortunately, for many teachers, CPD has been passive, one-shot workshops, designed by the administration and imposed on teachers for their implementation (Tabatabaee-Yazdi, Motallebzadeh, Ashraf, \& Baghaei, 2018). Therefore, training aspects are instrumental in shaping the personality of a teacher. It requires to be focused, purposeful, planned, and a continuous process. Such training is called Continuous Professional Development (Ilyas \& Zamir, 2020). Accordingly, Borg (2018) has maintained that effective CPD can impact a teacher's level of satisfaction, language proficiency, content or subject matter knowledge, instructional skills, attitudes, beliefs, and reflective competence, which in turn have the power to effect teachers' success. Another influence of teacher CPD is to aid teachers keep their enthusiasm and energy levels throughout their professional careers (Richards, 2015). Thus, Soodmand, Fazelimanie, and Doosti (2017) have highlighted that what is necessary for the life-long professional growth of the practicing teachers, which should be focused on in CPD courses, workshops, and other CPD programs, is attention to teachers' CPD needs. They also added detail that these CPD needs can be put in some clusters like teachers' classroom-related knowledge and skills needs, teachers' personal and interpersonal qualities, and teachers' pedagogical knowledge needs (Soodmand et al., 2017). According to Lindsay, Goodall, Day, Muijs, and Harris (2005), many leaders who contributed to the organization of CPDs reported their perceptions about the most effective CPD programs. There are some most important five CPDs for these leaders instance of Secondments/ sabbaticals, INSET days (In-service training days), Mentoring/ critical friendships, Informal networking with colleagues, and Series of workshops. Moreover, Diaz-Maggioli (2004) stated that CPD programs provide teachers with the time and materials to reflect together on teaching methods, and help them to share their teaching experiences, and as a result, teaching will effectively happen and developments take place. Accordingly, CPD points to four major layers of change development parallel to each other. One layer relates to changes in students, reflecting how students learn and what teachers need to know and are able to do to educate their students. The second layer reflects how teachers learn and what they need to know and are able to do to educate their students. The third layer shows how the change in teacher and student influences the whole school development. The fourth later is the social which is the outcome of the change reflected in the three layers described (Fadl, 2019). Day (1999), covering more aspects of the notion of CPD, reported learning experiences which occur naturally as one aspect. Thus, professional development consists of all-natural learning experiences and those conscious and planned activities which are intended to be of direct or indirect benefit to the individual, group, or institute, which contribute, through these, to the quality of education in the classroom (Day, 1999).

One of the key influential factors that help teachers to move toward efficiency is their creativity (Mahayana, Artini, \& Padmadewi, 2020) since nowadays critical thinking and creative thinking abilities are the main focus of learning (Beghetto \& Kaufman, 2014; Narmaditya, Wulandari, \& Sakarji, 2018). In second or foreign language classes, teachers' creativity is so important to win students' attention in the classroom (Triningsih \& Ghozali, 2018).Overall, Beghetto and Kaufman (2014) define creativity as the aptitude to produce high quality, novel, and appropriate work; the ability to perceive the world in new ways; and the capability to make associates between unrelated phenomena to generate workable solutions, regardless of the level. Creativity plays a critical role in all fields particularly in language teaching (Mirzaee \& Rahimi, 2017). The frameworks of 21 st-century learning skills are communication, collaboration, critical thinking, and creativity (Anjani, Maridi, \& Suciati, 2018). In terms of English teaching, Cremin (2015) describes the opportunity for creativity as active engagement, freedom in choice, and the use of knowledge as well as skills

International Journal of Educational
Studies
Volume 4, Issue 1, pp. 1-9
2021
DOI: 10.53935/2641-533x.v4i1.50
Corresponding Author: Fatemeh
Mohammadifar
Email: mohammadifar.f1994@ gmail.com
Funding: This study received no specific
financial support.
Article History:
Received: 28 June 2021
Revised: 30 July 2021
Accepted: 19 August 2021
Published: 1 September 2021
○ 2021 by the authors; licensee Academic
Publishing Group
Publishing Group 
to reflect on the learning experience. Creative teachers are people who master science (experts) and have autonomy (learning) in the classroom (Meliala, Purba, Panjaitan, Doloksaribu, \& Tarigan, 2021; Ufrah, 2020). As reported by Hrešć (2016), creative teachers should take risks. He believed that they must forsake the established teaching strategies and practices and apply the innovative method instead of some mentioned ways of teaching in the teachers' guide (Hrešć, 2016). Moreover, creative teachers solve the classroom problems with distinct and various solutions in order to promote students' success in education $(\mathrm{Gu}, 2017$; Selkrig \& Keamy, 2017). Nevertheless, in designing entrepreneurship education needs highly creative teachers so that they accomplish predicted goals (Samuel \& Rahman, 2018). According to Johnson (2017), the interaction between teachers' and students' energies causes to generate the classroom creativity that such a classroom is created with teachers' facilitation. Thus, the creativity of the teacher is very important to involve learners in the learning process (Mahayana et al., 2020).

\section{Methodology}

3.1. Participants

This research aims to investigate the relationship between Iranian EFL Teachers' CPD and their creativity. Therefore, considering all the study's research questions, this study invited 210 participants (81 (37\%) Males and 129 (61\%) Females) to take part in the study. They were selected based on convenient sampling, using Google Form link, due to the Corona Virus Pandemic. The teachers were from different fields of study within the domain of English Language (English language teaching, translation, and English literature). The majority of the participants $(62 \%)$ studied TEFL, (12\%) English translation, (11\%) English literature, and (15\%) other fields. About $27 \%$ of participants were BA holders, $62 \%$ were MA holders, $6 \%$ were Ph.D. holders, and about 5\% were AA and diploma holders. Teachers' age range was between 19 to 44 (Mean=30, SD=7.1). About 36\% of them had 0-5 years of teaching experience, $23 \%$ between 6 to 10 , and $42 \%$ had more than 10 years of teaching experience.

\subsection{Instrumentation}

\subsubsection{Continuing Professional Development (CPD) Questionnaire}

Continuing Professional Development (CPD) Questionnaire was developed and validated by TabatabaeeYazdi et al. (2018). The questionnaire includes 20 items on a five-point Likert scale ranging from "No impact to a large impact". It includes four sub-constructs as updating, collaborating, decision-making, and reflecting. The reliability of this test was estimated using Cronbach's alpha coefficient of 0.8 .

\subsubsection{Creativity Questionnaire}

Creativity questionnaire developed and validated by Cropley (1997). This questionnaire consists of 45 items on a six-point Likert scale ranging from (1) never to (6) all the time. The scale has nine factors including independence, integration, motivation, judgment, flexibility, evaluation, questions, opportunities, and frustration. The Cronbach's alpha coefficient of the test is reported as 0.9 (Cropley, 1997).

\subsection{Procedures}

To determine the relationship between the two variables in this quantitative-correlational study, 210 Iranian EFL teachers have participated in this study based on convenient sampling. For gathering the data two questionnaires were administered through Google Form that shared via social media like Telegram and WhatsApp. The gathered data are analysed via SPSS software. Pearson product-moment correlation and Structural equation modelling (SEM) were run to answer the first and second research questions. Questions three and four are analysed by running an independent-sample t-test and ANOVA.

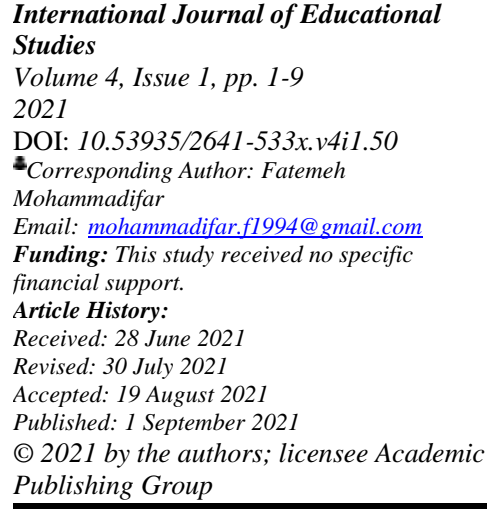

\section{Results}

Checking normality of the data distribution using the Kolmogorov-Smirnov test, it is safely concluded that the data was normally distributed across both variables. Also, the descriptive statistics illustrated that the mean score of overall CPD is 34.66 with a standard deviation of 10.36, and the mean score of teachers' reports on the overall creativity scale is 215.70 with a standard deviation of 30.80 .2 . moreover, the utilized questionnaires gained acceptable indexes of Cronbach alpha for both variables (overall $\mathrm{CPD}=.88$, overall 
Creativity=.95). The reliability of the CPD questionnaire for the subscales ranges from .83 to .90 which is an acceptable range and the reliability of the subscales of creativity ranges from .79 to 91 .

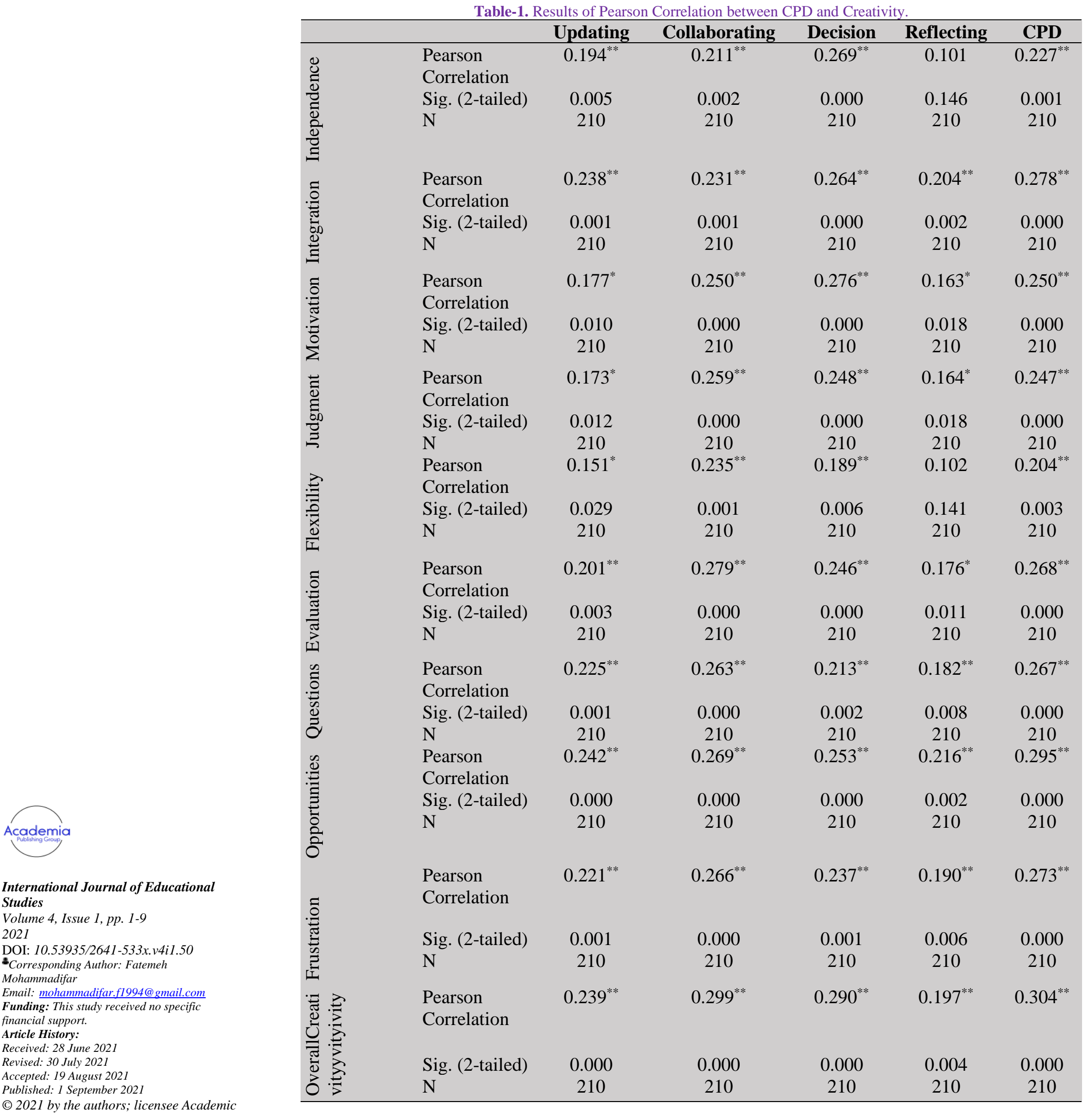


To answer the first research question which aims to find the relationship between Iranian EFL teachers' CPD and their creativity, Pearson-product-moment correlation was used. The results showed that Table 1 there is a significant correlation between all the four sub-scales of CPD and nine sub-scales of creativity. Moreover, there is a positive significant relationship between overall CPD and overall creativity $(\mathrm{r}=.30$, $\mathrm{p}<.05)$. Based on the results, it was also found that Updating has the highest correlation with Opportunities ( $\mathrm{r}=$ $.24, \mathrm{p}<.05)$, Collaborating with Evaluation $(\mathrm{r}=.27, \mathrm{p}<.05)$, Decision-making with Motivation $(\mathrm{r}=.27, \mathrm{p}<.05)$, and Reflecting with Opportunities $(\mathrm{r}=.21, \mathrm{p}<.05)$. To answer the second research question and to confirm the proposed model of interrelationships among teachers' CPD and creativity, SEM was employed using AMOS software. Figure 2 shows the proposed model of the interrelationship among variables. The model hypothesized that four sub-scales of CPD are predictors of teachers' creativity. Results of the SEM revealed that all four subscales of CPD are positive significant predictors of overall creativity: Updating $(\beta=.21, p<.05)$, Collaborating $(\beta=.27, p<.05)$, Decision-making $(\beta=.26, p<.05)$, and Reflecting $(\beta=.18, p<.05)$. Based on the results of SEM, among four subscales of CPD, Collaborating is the best predictor of Iranian EFL teachers' creativity.

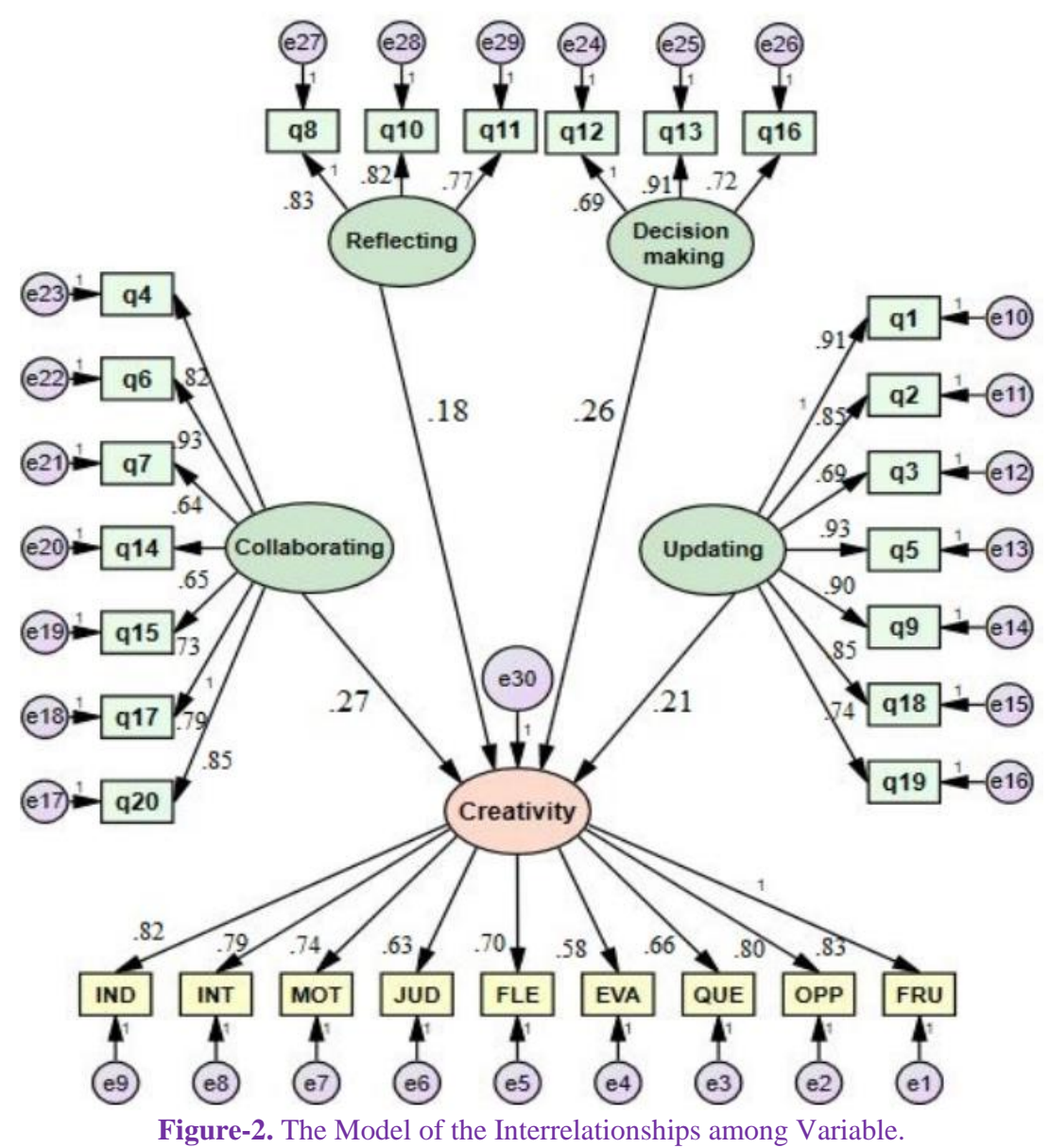

International Journal of Educational Studies

Volume 4, Issue 1, pp. 1-9

2021

DOI: $10.53935 / 2641-533 x . v 4 i 1.50$

Corresponding Author: Fatemeh

Mohammadifar

Funding: This study received no specific

financial support.

Article History:

Received: 28 June 202

Revised: 30 July 2021

Accepted: 19 August 2021

Published: 1 September 2021

(C) 2021 by the authors; licensee Academic Publishing Group
Table-2. Results of the Independent-Samples T-Test for Gender Difference.

\section{t-test for Equality of Means}

\begin{tabular}{cccccc}
\hline & T & df & Sig. (2-tailed) & Mean Difference & Std. Error Difference \\
Creativity & -1.50 & 208 & 0.13 & -6.56 & 4.35 \\
\hline
\end{tabular}


Table 3 shows the results of the one-way ANOVA for finding out the differences between teachers' creativity concerning their years of teaching experiences. As the Table shows, there is not any significant difference between the three groups $(\mathrm{F}=2.74, \mathrm{p}=.06)$.

\section{Discussion}

As the results of the study exhibited, there is a significant relationship between teachers' CPD and teachers' Creativity which is in line with Arifani, Mohd Khaja, Suryanti, and Agus, (2019) who discovered the influence of blended teacher professional training on teaching creativity and teaching effectiveness from the learners' perspective. It is also believed that creative EFL teaching is generated by creative EFL teachers (Suwartono \& Oktavia, 2019). Also, Suwartono and Oktavia (2019) explained that creative teachers should be knowledgeable and updated, confident, committed to helping their learners succeed, familiar with a variety of strategies and techniques, risk-takers, and reflective. Therefore, EFL teachers could develop their creativity by familiarizing themselves with some professional development activities like reading journals, taking part in conferences, symposiums, seminars, training, and workshops since such activities give an opportunity to teachers for intense communication in order to obtain new and modern information, practical ideas and experiences (Suwartono \& Oktavia, 2019). It is in accordance with Brereton and Kita (2020) who considered teachers' beliefs and identities about collaboration as one key component for professional development that help them to develop creativity into a real habit. They also explained that EFL teachers develop creativity with collaboration which is a crucial factor to be successful. Yu (2017) discussed the elements of creativity and collaborative mentoring to develop teachers' creative practices. Moreover, Sharma (2019) explained that EFL teachers who can decide to apply technology and social media as creative teaching strategies are more efficient in their job. In addition, the other researchers have focused on using methods that give students more freedom and autonomy to express themselves (Alonazi, 2017; Javid, 2018) instance of the administration of flipped classrooms (Al-Ghamdi \& Al-Bargi, 2017), and the advancement of collaboration (Roy, 2016). Therefore, social media as updating and collaborating of subscales of CPD linked to elements of creativity. Furthermore, the result displayed that reflection as the basis of creativity allowed teachers to make a creative product with the best methods. Besides, the results of this study provide evidence that there is no significant difference in the level of EFL teachers' creativity between male and female and years of teaching experience teachers which are in accordance with Nikoopour and Torabi (2017) reported that gender made no significant difference in their creativity and cognition about their teaching profession. However, Khodabandeh and Jamali (2019) revealed that there is a significant difference between Iranian EFL male and female teachers concerning their attitudes towards creativity.

Table-3. Results of the one-way ANOVA.

\begin{tabular}{lccccc}
\hline & Sum of Squares & df & Mean Square & F & Sig. \\
\hline Between Groups & 5127.646 & 2 & 2563.823 & 2.747 & 0.066 \\
Within Groups & 193218.454 & 207 & 933.422 & & \\
Total & 198346.100 & 209 & & & \\
\hline
\end{tabular}

\section{Conclusion}

To sum up, the study's findings showed that there was a positive significant relationship between overall CPD and overall creativity in Iranian EFL teachers. Moreover, the findings showed that all the subscales of CPD are positive significant predictors of overall creativity.. However, collaborating was the leading predictor of Iranian EFL teachers' creativity. As a result, it is noticeable that encourage teachers to collaborate with other colleagues, to receive updated materials and information, to keep reflections can produce higher creativity in teachers. In addition, the result of the study showed that there is no significant difference between gender and years of teaching experience in Iranian EFL teachers' creativity. According to the findings, this study concluded that the role of teachers is a prominent factor in the educational settings. In other words, based on this research one factor that can be effected on the quality of teachers is creativity that is proven to be supported and enhanced by teachers' CPD. Therefore, teachers' creativity could prosper when EFL teachers participated in some activities of professional development. Besides, encouraging teachers to collaborate and consult with experienced individuals and to apply updated materials can improve teachers'

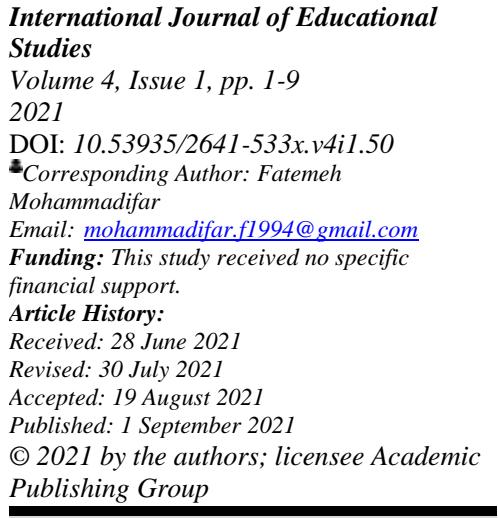


creativity. Results of this study could be of great help for teachers and researchers to enhance their creativity skills. It provides a framework for both teachers and learners to be aware of perceptions about creativity and activities that help to boost it. In addition, it can be a great help for teachers to follow CPD programs to enhance their creativity that is one factor for motivation in the educational field. It is an aid for administrators of English language institutes with conscious of beneficial practices and activities of CPD to elevate teachers' creativity knowledge and education. In this research was visible that if EFL teacher faced challenges in their classroom, they could solve them with the relevant and practical workshops in CPD. The researcher only deliberated male and female EFL teachers in Iran with different years of experience. further research could apply the instruments with other sample settings to generalization the findings or to follow with a different result and could examine CPD association with the other components like students' success or students creativity.

\section{References}

Al-Ghamdi, M., \& Al-Bargi, A. (2017). Exploring the application of flipped classrooms on EFL Saudi students' speaking skill. International Journal of Linguistics, 9(4), 28-46. Available at: https://doi.org/10.5296/ijl.v9i4.11729.

Alonazi, S. M. (2017). The role of teachers in promoting learner autonomy in secondary schools in Saudi Arabia. English Language Teaching, 10(7), 183-202. Available at: https://doi.org/10.5539/elt.v10n7p183.

Anjani, D., Maridi, M., \& Suciati, S. (2018). Inquiry based learning module to empower cooperation skills. Journal of Education and Learning, 12(2), 172-178. Available at: https://doi.org/10.11591/edulearn.v12i2.8268.

Appu, A. V., Sia, S. K., \& Sahoo, B. C. (2015). Creativity at workplace: Proposing some contributors. International Journal of Innovative Research and Development, 4(5), 177-183.

Arifani, Y., Mohd Khaja, F. N., Suryanti, S., \& Agus, W. (2019). The influence of blended in-service teacher professional training on EFL teacher creativity and teaching effectiveness. The Southeast Asian Journal of English Language Studies, 25(3), 126 - 136. Available at: http://doi.org/10.17576/3L-2019-2503-10.

Beghetto, R. A., \& Kaufman, J. C. (2014). Classroom contexts for creativity. High Ability Studies, 25(1), 53-69. Available at: https://doi.org/10.1080/13598139.2014.905247.

Borg, S. (2018). Evaluating the impact of professional development. RELC Journal, 49(2), 195-216.

Brereton, P., \& Kita, S. (2020). Exploring teacher creativity through duoethnography and reflection. Teacher Development Academic Journal, 1(1), 7-19.

Cremin, T. (2015). Teaching english creatively. Learning to teach in the primary school series (2nd ed.). Abingdon: Routledge.

Cropley, A. J. (1997). Fostering creativity in the classroom: General principles. In M. A. Runco. (Ed.) Creativity research handbook (Vol. 1, pp. 83-114). Cresskill, N. J: Hampton Press.

Day, C. (1999). Professional development and reflective practice: Purposes, processes and partnerships. Pedagogy, Culture \& Society, 7(2), 221-233. Available at: https://doi.org/10.1080/14681366.1999.11090864.

Dewi, N. (2019). Cognition, conscience, and creativity: Multimedia-based literature teaching for pre-service teachers in Indonesia. 3L: Language, Linguistics, Literature ${ }^{8}, 25(2)$, 86-98. Available at: https://doi.org/10.17576/31-20192502-07.

Diaz-Maggioli, G. (2004). Teacher-centered professional development. Alexandria, VA: Association for Supervision and Curriculum Department.

Fadl, E. E. M. A. (2019). The necessity of continuing professional development for EFL teachers. Gezira Journal of Educational Sciences and Humanities, 16(1), 1-17.

$\mathrm{Gu}, \mathrm{C}$. (2017). On the relationships between creative learning, creative teaching, and roles of creative teachers. In handbook of research on creative problem-solving skill development in higher education (pp. 494-512). China: Central China Normal University.

Hrešć, T. (2016). Ways of promoting creativity in EFL classroom. Master's Thesis.

Ilyas, M., \& Zamir, S. (2020). CPD of university teachers in Pakistan: challenges and prospects. ISSRA Papers, 12(1), 113-124.

Ismail, N., Desa, S., \& Balakrishnan, B. (2018). Science creative teaching design for science teachers. International Journal of Academic Research in Business and Social Sciences, 8(4), 1235-1241.

Javid, C. Z. (2018). A Gender-based Investigation of the Perception of English Language Teachers at Saudi Universities Regarding the Factors Influencing Learner Autonomy. Arab World English Journal, 9(4), 310-323. Available at: https://doi.org/10.24093/awej/vol9no4.23.

Johnson, I. (2017). Creative teaching: Using creative teaching methods in a student-centered EFL environment. Master's Project.

Khodabandeh, F., \& Jamali, M. (2019). Exploring the relationship between teachers' creativity, classroom management, age and gender. Journal of Foreign Language Teaching and Translation Studies, 4(1), 67-88. 
Komba, W. L., \& Nkumbi, E. (2008). Teacher professional development in Tanzania: Perceptions and practices. Journal of International Cooperation in Education, 11(3), 67-83.

Lindsay, G., Goodall, J., Day, C., Muijs, D., \& Harris, A. (2005). Evaluating the impact of continuing professional development $(C P D)$. London: Department for Education.

Mahayana, D. H., Artini, L. P., \& Padmadewi, N. N. (2020). Perceive and observed teaching creativity of English teachers in SMKN 1 Negara. International Journal of Language and Literature, 4(1), 22-32. Available at: https://doi.org/10.23887/ijll.v4i1.30223.

Meliala, E. P., Purba, P. W. R., Panjaitan, L., Doloksaribu, L., \& Tarigan, N. W. P. (2021). An analysis of english teachers'creativity in media-based learning at the tenth-grade students. Journal of Languages and Language Teaching, 9(1), 105-110. Available at: https://doi.org/10.33394/jollt.v9i1.3388.

Mirzaee, A., \& Rahimi, M. (2017). An investigation on relationship between Iranian EFL teachers' creativity and classroom management strategies and learners' improvement. Journal of Advances in English Language Teaching, 5(4), 31-45.

Narmaditya, B. S., Wulandari, D., \& Sakarji, S. R. B. (2018). Does problem-based learning improve critical thinking skill? Jurnal Cakrawala Pendidikan, 37(3), 378-388.

Nikoopour, J., \& Torabi, S. (2017). EFL Teachers' creativity and their cognition about teaching profession. Journal of Applied Linguistics and Language Learning, 3(1), 1-8.

Padwad, A., \& Dixit, K. (2011). Continuing professional development: An annotated bibliography. New Delhi: British Council, India.

Refrigeri, P. L. (2018). Beyond the law. the CPD model for the professional development of future teachers. AGORA International Journal of Juridical Sciences, 11(2), 124-132.

Rhodes, M. (1987). An analysis of creativity. In S. G. Isaksen (Ed.) Frontiers of creativity research: beyond the basics. Buffalo, NY: Bearly Limited.

Richards, J. C. (2015). Key issues in language teaching (pp. xxii + 848). Cambridge, UK: Cambridge University Press.

Roy, C. K. (2016). Be creative and collaborative: Strategies and implications of blogging in EFL classes. English Language Teaching, 9(7), 129-145. Available at: https://doi.org/10.5539/elt.v9n7p129.

Samuel, A. B., \& Rahman, M. M. (2018). Innovative teaching methods and entrepreneurship education: A review of literature. Journal of Research in Business, Economics and Management, 10(1), 1807-1813.

Seddigh, F., \& Shokrpour, N. (2013). Creativity and its relationship with vocabulary learning strategy use of EFL students. Journal of Studies in Education, 3(2), 139-151. Available at: https://doi.org/10.5296/jse.v3i2.3199.

Selkrig, M., \& Keamy, K. (2017). Creative pedagogy: A case for teachers' creative learning being at the centre. Teaching Education, 28(3), 317-332. Available at: https://doi.org/10.1080/10476210.2017.1296829.

Sharma, V. (2019). Saudi students' perspective on social media usage to promote EFL learning. Online Submission, 2(1), 129-139. Available at: https://doi.org/10.32996/ijllt.2019.2.1.17.

Soh, K. C. (2000). Indexing creativity fostering teacher behavior: A preliminary validation study. The Journal of Creative Behavior, 34(2), 118-134. Available at: https://doi.org/10.1002/j.2162-6057.2000.tb01205.x.

Soodmand, A. H., Fazelimanie, A., \& Doosti, M. (2017). Developing an inventory to investigate current professional development needs of Iranian EFL teachers. Teaching English Language, 11(2), 161-194.

Sternberg, R. J. (1985). Beyond IQ: A triarchic theory of human intelligence. New York: Cambridge University Press.

Suwartono, T., \& Oktavia, N. F. (2019). In search of creative EFL teachers: a perspective from best classroom practices. Ahmad Dahlan Journal of English Studies, 6(1), 9-19.

Tabatabaee-Yazdi, M., Motallebzadeh, K., Ashraf, H., \& Baghaei, P. (2018). Continuing professional development strategies: A model for the Iranian EFL teachers' success. SAGE Open, 8(1), 2158244018764234. Available at: https://doi.org/10.1177/2158244018764234.

Triningsih, E., \& Ghozali, I. (2018). Teachers' creativity in developing speaking skill of junior high school students in yogyakarta. Journal of English Language and Pedagogy, 1(1), 1-11. Available at: https://doi.org/10.36597/jelp.v1i1.2793.

International Journal of Educational Studies

Volume 4, Issue 1, pp. 1-9

2021

DOI: $10.53935 / 2641-533 x . v 4 i 1.50$

Corresponding Author: Fatemeh

Mohammadifar

Email: mohammadifarf1994@ gmail com

Email: mohammadifar.f1994@gmail.con

Funding: This study received no specific

financial support.

Article History:

Revised: 30 July 2021

Accepted: 19 August 2021

Published: 1 September 202

(C) 2021 by the authors; licensee Academic

Publishing Group
Ufrah. (2020). Teachers' creativity and belief in using group work as EFL classroom management strategy. Masters Thesis, IAIN Parepare.

Ukpo, E. O. (2005). Professionalisation of teachers in Nigeria: challenges and obstacles. In African Symposium: An OnLine African Educational Research Journal, 5(2), 86-94.

Yu, C. X. (2017). A mentoring approach for developing creativity in teaching. Malaysian Journal of ELT Research, 14(2), 1-19. 